Review Article

\title{
Current Status of Canine Umbilical Cord Blood-Derived Mesenchymal Stem Cells in Veterinary Medicine
}

\author{
Tania Sultana, ${ }^{1}$ Soojung Lee $\mathbb{D}^{1,2}$ Hun-Young Yoon, ${ }^{3}$ and Jeong Ik Lee $\mathbb{D}^{1,4}$ \\ ${ }^{1}$ Regenerative Medicine Laboratory, Center for Stem Cell Research, Department of Biomedical Science and Technology, Institute of \\ Biomedical Science and Technology, Konkuk University, Seoul, Republic of Korea \\ ${ }^{2}$ Regeniks Co. Ltd., Seoul, Republic of Korea \\ ${ }^{3}$ Department of Veterinary Surgery, College of Veterinary Medicine, Konkuk University, Seoul, Republic of Korea \\ ${ }^{4}$ Department of Veterinary Obstetrics and Theriogenology, College of Veterinary Medicine, Konkuk University, \\ Seoul, Republic of Korea
}

Correspondence should be addressed to Jeong Ik Lee; jeongik@konkuk.ac.kr

Received 20 April 2018; Accepted 19 June 2018; Published 15 July 2018

Academic Editor: Huseyin Sumer

Copyright ( 2018 Tania Sultana et al. This is an open access article distributed under the Creative Commons Attribution License, which permits unrestricted use, distribution, and reproduction in any medium, provided the original work is properly cited.

\begin{abstract}
Stem cell therapy has prompted the expansion of veterinary medicine both experimentally and clinically, with the potential to contribute to contemporary treatment strategies for various diseases and conditions for which limited or no therapeutic options are presently available. Although the application of various types of stem cells, such as bone marrow-derived mesenchymal stem cells (BM-MSCs), adipose tissue-derived mesenchymal stem cells (AT-MSCs), and umbilical cord blood-derived mesenchymal stem cells (UCB-MSCs), has promising potential to improve the health of different species, it is crucial that the benefits and drawbacks are completely evaluated before use. Umbilical cord blood (UCB) is a rich source of stem cells; nonetheless, isolation of mesenchymal stem cells (MSCs) from UCB presents technical challenges. Although MSCs have been isolated from UCB of diverse species such as human, equine, sheep, goat, and canine, there are inherent limitations of using UCB from these species for the expansion of MSCs. In this review, we investigated canine UCB (cUCB) and compared it with UCB from other species by reviewing recent articles published from February 2003 to June 2017 to gain an understanding of the limitations of cUCB in the acquisition of MSCs and to determine other suitable sources for the isolation of MSCs from canine. Our review indicates that cUCB is not an ideal source of MSCs because of insufficient volume and ethical issues. However, canine reproductive organs discarded during neutering may help broaden our understanding of effective isolation of MSCs. We recommend exploring canine reproductive and adipose tissue rather than UCB to fulfill the current need in veterinary medicine for the welldesigned and ethically approved source of MSCs.
\end{abstract}

\section{Introduction}

In the last 20 years, stem cells have received ample attention from researchers in both human and veterinary medicine for their functional characteristics and therapeutic potential in different applications [1-4]. The number of animals previously treated in veterinary medicine provides a consequential basis for estimating the effectiveness of stem cell therapy in the treatment of different diseases $[5,6]$. Nearly all types of animal tissues can be repaired or regenerated by the explicit action of stem cells [7], which exhibit high potential for propagation and differentiation [8]. Moreover, animal models are extensively used to examine the properties and promising potential of stem cells for reasonable application in human medicine in the future. Consequently, human and veterinary medicine are intertwined in the emerging field of stem cell research. Pioneering innovations in stem cell research have been accomplished by the collaboration of clinical and veterinary scientists.

For instance, adult stem cells isolated from various sources, mainly bone marrow- (BM-) and adipose tissue(AT-) derived stem cells, have been widely used for the treatment of different animal diseases $[9,10]$. As in human medicine, adult mesenchymal stem cells (MSCs) play an 
important role in veterinary medicine for the treatment of acute injury and chronic disorders. In brief, MSCs, also known as marrow stromal cells [11] or mesenchymal progenitor cells, are considered the most heavily utilized stem cells in the field of regenerative medicine and tissue engineering $[12,13]$ to overcome the complications and limitations of gene-based therapies. Currently, MSCs are used in clinical cell therapies and trials in many countries [14] for their in vitro expansion, notable multilineage differentiation potential $[15,16]$, capability to treat tissue injury $[17,18]$, viability after long-term storage by cryopreservation [19], support of hematopoietic stem cell (HSC) expansion as feeder cells [20], and immunomodulatory properties [21, 22]. These extensively applied cells were first depicted by Friedenstein et al. as a cell population analogous to fibroblasts [23]. They have the potential to differentiate into numerous cell types such as osteoblasts, adipocytes, cardiomyocytes, chondrocytes, hepatocytes, and brain cells [24-35]. These cells can be isolated from $\mathrm{BM}$, AT, peripheral blood, skeletal muscle, connective tissue of the dermis, and Wharton's jelly (WJ) as well as umbilical cord blood (UCB) [30, 36-39].

Although BM represents an abundant source of MSCs $[33,40]$ in the field of tissue engineering and cell-based therapy, harvesting of cells is invasive with a stringent donor age requirement and increased donor site morbidity [41-46]. Therefore, UCB has been identified as an ideal alternative source in terms of ease of accessibility as well as reduced morbidity. UCB carries a large number of MSCs per volume, which are more flexible and pluripotent than bone marrowderived mesenchymal stem cells (BM-MSCs) [38, 47]. Additionally, it has been proposed that umbilical cord bloodderived mesenchymal stem cells (UCB-MSCs) are not as mature as other stem cells and may not induce alloreactive responses that harmonize the immune system [32, 48, 49] and have the lower carcinogenic potential [50].

Nevertheless, although the presence of HSCs and their isolation from UCB are well established [51-54], the statistics concerning the existence of UCB-MSCs are contentious and require further evaluation. Earlier experiments to isolate UCB-MSCs from different species have either been aborted, have been time-consuming and onerous [55-57], or have been only 30-60\% effective under suitable conditions [38, 39, 58-63].

UCB-MSCs can be isolated from different species such as human $[37,58,59,64-74]$, sheep $[75,76]$, equine [77-79], canine [80-84], and goat [85]. Human UCB-MSCs (hUCBMSCs) are collected noninvasively at the time of delivery, whereas sheep UCB is collected intrusively by the surgical intrauterine approach $[75,76]$. Equine UCB represents a noninvasively and nontraumatically retrieved source of stem cells, with potentially excellent cellular characteristics including proliferation capacity, immune tolerance, and differentiation potency [78]. It is reported that UCB from more than 100 mares and foals has been collected safely and efficaciously. The enrichment rate of MSCs from equine UCB is very high compared with that of other species [86].

Canine and feline are mainly considered companion animals rather than laboratory animals. Generally, pet owners prefer their pet (canine and feline) to be neutered (spayed or castrated) for the purpose of sterilization. After spay, canine UCB (cUCB) is impossible to collect, as the females lose their reproductive capability. In this view, cUCB raises the problem of limited availability. Yet, there are a few studies on the successful isolation and application of canine UCB-MSCs (cUCB-MSCs).

Even though UCB-MSCs are the latest tool and have already been commercialized for human medicine, the progress of UCB-MSC research in veterinary medicine is at a standstill. Therefore, veterinary medicine must overcome the major challenges of UCB-MSCs. We know that CUCBMSCs have a great impact on veterinary medicine. Thus, cUCB-MSCs should be further explored to boost the supply thereof. In this respect, this is the first review that highlights the limitations of $\mathrm{CUCB}$ for the isolation of MSCs and suggests another significant source of MSCs in canine.

\section{Umbilical Cord Blood and Mesenchymal Stem Cells}

The umbilical cord, also known as the navel-string or birth cord, is the channel between the growing placenta and fetus. In the course of prenatal development, the umbilical cord is a physiological and inherent part of the fetus. Typically, the umbilical cord consists of two arteries (the umbilical arteries) as well as one vein (the umbilical vein) buried in WJ, a gelatinous element composed largely of mucopolysaccharides. The two umbilical arteries transfer deoxygenated, nutrient-diminished blood away, whereas the umbilical vein carries oxygenated, nutrient-boosted blood to the fetus. The umbilical cord is covered by an epithelium obtained from the enveloping amnion.

UCB has been utilized as a rich and readily available alternative source of primitive and unspecialized stem cells since 1988 [87]. The blood remaining in the umbilical vein after birth is an abundant source of hematopoietic stem and progenitor cells. This criterion makes UCB an allogenic donor source that can be applied in a variety of hematologic, pediatric, genetic, oncologic, and immunologic disorders [53, 88-90]. Fresh UCB is also an auspicious source of non-HSCs such as MSCs, endothelial cells, and unrestricted somatic stem cells [30,91-93]. Although several previously published articles reported the identification of MSCs in UCB $[38,39]$, some authors debated the existence of MSCs in UCB and declared that only HSCs are present therein $[56,94]$. The origin of MSCs in UCB is unrecognized, but it is possible that the cells are discharged from the fetal liver or bone marrow into the fetal circulation [65]. Presently, the isolation of MSCs from UCB has a lower success rate compared with BM-MSCs (63\% versus 100\%) [67]. AT is another alternative source that can be accessed less invasively and repeatedly with an easy procedure, resulting in larger quantities of fresh MSCs [95].

\section{Process of Article Selection}

We utilized the search engines PubMed and Google Scholar to gather a list of publications and manuscripts detailing 
research, employment, or isolation of MSCs from human and animal subjects from February 2003 to June 2017. For a report to be included in this survey, it must have contained "Umbilical Cord Blood-derived Mesenchymal Stem Cells (UCB-MSCs)" in either the heading or the abstract. The keyword "Umbilical Cord Blood-derived Mesenchymal Stem Cells (UCB-MSCs)" combined with "human," "equine," "sheep," "goat," and "canine" was used to generate the list. We did not include any review articles in our survey. Highly relevant articles were initially determined by the heading and abstract, followed by a further examination to confirm whether the collection of UCB was from human or animal subjects. We accept that this search technique was not encyclopedic, as there are many more articles in journals that are not included in PubMed or Google Scholar. We evaluated the listed studies by different characteristics such as the weight of the species, final blood volume, and enrichment rate of MSCs.

For studies in which UCB-MSCs were isolated from humans, the key areas recognized were ethics (informed consent was obtained), route of delivery, UCB unit and volume, and MSC success rate. For studies in which UCBMSCs were isolated from animals, the key areas noted were ethics (reporting of omission and approval of the study by the Animal Care and Use Committee), study design (distribution of groups and sample number and volume), route of delivery, and experimental animals (species, breed, and weight).

\section{UCB-MSC Articles Entailing Human and Animal Sources}

The electronic search singled out 130 articles. A total of 20 articles based on human and animal sources of UCB-MSCs were considered based on the heading, abstract, and content (species, UCB unit and volume, and MSC success rate). Review articles, duplicates, and irrelevant papers were removed. In total, 55\% (11/20) of articles reported human subjects, and $45 \%$ (9/20) of papers reported animal subjects, such as equine, sheep, goat, and canine (Table 1). Nine articles regarding human subjects stated that UCB was collected with the informed consent of the mothers, while four studies detailing animal subjects received approval from an animal ethics committee (Table 2).

\section{Success Rate of MSC Isolation from UCB}

Some researchers successfully isolated $33.3 \%-60 \%$ of hUCBMSCs under different cell culture conditions [69, 71]. Bieback et al. reported that a net volume of more than $33 \mathrm{~mL}$ of UCB and a mononucleated cell (MNC) count higher than $1 \times 10^{8}$ are difficult to achieve for the isolation of UCB-MSCs from human subjects. However, they were capable of increasing the success rate from $29 \%$ to $63 \%$ [37]. Jin et al. reported the isolation of $50 \%$ of UCB-MSCs from 24 pregnant women [67]. When the blood volume exceeds $90 \mathrm{~mL}, 90 \%$ of MSCs from UCB can be isolated $[66,70]$. Liu et al. stated that the efficacy of MSC isolation from UCB can reach $75 \%(n=144)$ [72]. Sibov et al. and
TABLE 1: Articles included in this survey regarding UCB-MSCs from different species.

\begin{tabular}{lcc}
\hline Sources of UCB & Reference & Number of articles \\
\hline Human & {$[20,37,58,65-67,69-73]$} & 11 \\
Animal & {$[75-78,80,82-85]$} & 9 \\
\hline
\end{tabular}

Johannes et al. demonstrated that more than $70 \mathrm{~mL}$ of UCB is required for the successful isolation of MSCs $[70,73]$. On the other hand, Thomas et al. isolated equine UCB-MSCs from a volume of $42 \mathrm{~mL}$ at a $100 \%$ success rate with PrepaCyte-EQ (PEQ) medium. The same authors isolated MSCs with a success rate of $57 \%$ from a volume of $65-250 \mathrm{~mL}$ of equine UCB $[77,78]$. Different authors have investigated the isolation of MSCs from UCB of goat and sheep (Table 3) [76, 85].

Although Kang et al. and Jang et al. separately continued their experiments with cUCB-MSCs, they did not explicitly provide any information about the blood volume and number of canine subjects they used $[80,83]$. Lim et al. successfully isolated MSCs from an exceedingly low UCB volume of $8 \mathrm{~mL}$ [84]. As the UCB volume of canine is insufficient to isolate MSCs, another author utilized the blood of canine fetus heart along with UCB [82] (Tables 4 and 5).

\section{MSCs in Human and Veterinary Medicine}

The application of stem cells in cell-based therapies and tissue engineering is increasing to overcome the complications and hurdles of gene therapy. In both animals and human, stem cell implantation can serve as an advanced treatment for some incurable conditions such as bone fracture malignancies [96, 97], spinal cord injuries [98], and genetic disorders [99]. Tables 6 and 7 summarize the application of MSCs in the treatment of a wide range of diseases in preclinical studies of experimental animal models and veterinary clinical studies of animals with naturally occurring diseases. In human medicine, MSC products have already been developed and approved in South Korea. Cartistem ${ }^{\circledR}$ (Medipost), the world's first allogenic hUCB-MSC drug, has gained popularity in South Korea since January 2012 for the treatment of cartilage injury and osteoarthritis, and efforts are presently being made to broaden its indications for different target diseases. However, the isolation and characterization of stem cells obtained from numerous tissues and sources have led to highly detracting arguments regarding stem cell therapy [100-102].

Stem cell researchers worldwide are endeavoring to acquire the ideal or optimal autologous or allogenic MSCs, not only from human but also from equine, canine, and feline, to treat diseases such as musculoskeletal diseases, degenerative arthritis, atopic dermatitis, myocardial disease, chronic renal failure, and nerve damage [103]. Based on the concept of "One Health," new synergistic therapies such as stem cell therapies for human and veterinary medicine are in increasing demand and developed in collaboration-the time for focus on human and animal health is now [104]. 
TABLE 2: Summary of ethical approval in studies that reported the collection of UCB from human and animal subjects.

\begin{tabular}{lcc}
\hline Ethics & \multicolumn{1}{c}{ Yes } & Nefence \\
\hline Informed consent from UCB donors & {$[20,37,58,65-67,69,70,73]$} & {$[71,72]$} \\
Approval from animal ethics committee & {$[75,80,84,85]$} & {$[76-78,82,83]$} \\
\hline
\end{tabular}

TABLE 3: Summary of papers that reported data regarding the isolation of UCB-MSCs from human, equine, sheep, and goat.

\begin{tabular}{|c|c|c|c|c|c|c|}
\hline Species & Breed & Route of delivery & UCB unit & UCB volume $(\mathrm{mL})$ & Frequency of MSCs (\%) & Reference \\
\hline Human & - & Vaginal & 10 & 50 & 60 & [71] \\
\hline Human & - & Cesarean & 35 & - & 40 & [69] \\
\hline Human & - & Vaginal & 13 & 60 & 46 & [20] \\
\hline Human & - & Vaginal & 59 & 108 & 63 & [37] \\
\hline Human & - & Vaginal & 24 & - & 50 & [67] \\
\hline Human & - & Vaginal & - & $\geq 80$ & 90 & {$[66,70]$} \\
\hline Human & & Cesarean & 456 & $\geq 90$ & 90.9 & [65] \\
\hline Human & - & Vaginal & 144 & - & 75 & {$[72]$} \\
\hline Human & - & Vaginal & 9205 & $40-321$ & - & [73] \\
\hline Human & - & Vaginal & 30 & - & 35 & [58] \\
\hline Equine & - & Vaginal & 7 & $65-250$ & 57 & [78] \\
\hline Equine & - & Vaginal & 5 & 42 & 100 & [77] \\
\hline Goat & Mongrel & Vaginal & - & - & - & [85] \\
\hline Sheep & Santa Ines & Surgical procedure & 5 & 100 & - & [76] \\
\hline Sheep & - & Surgical intrauterine approach & 4 & 10 & - & [75] \\
\hline
\end{tabular}

TABLE 4: Summary of papers that reported data regarding the isolation of MSCs from CUCB.

\begin{tabular}{|c|c|c|c|c|c|c|}
\hline Source of MSCs & Breed & Weight $(\mathrm{kg})$ & Route of delivery & UCB Unit & UCB Volume $(\mathrm{mL})$ & Reference \\
\hline cUCB & Mongrel & 58 & C-section & 1 & 8 & [84] \\
\hline cUCB and blood of canine fetus heart & - & - & - & - & - & [82] \\
\hline cUCB & - & - & C-section & - & - & {$[83]$} \\
\hline cUCB & Beagle & 10.1 & C-section & 7 & - & [80] \\
\hline
\end{tabular}

C-section: Cesarean section.

TABLE 5: Summary of purposes of cUCB studies.

\begin{tabular}{lcc}
\hline Purpose of experiment & Reference \\
\hline Transplantation of cUCB-MSCs in spinal cord injured dogs & {$[84]$} \\
Isolation and characterization of cUCB-MSCs & {$[82]$} \\
Implantation of cUCB-MSCs mixed with $\beta$-TCP to enhance osteogenesis & {$[83]$} \\
Comparison of osteogenic potential of canine MSCs derived from AT, BM, UCB, and WJ & {$[80]$} \\
\hline
\end{tabular}

$\beta$-TCP: beta-tricalcium phosphate.

\section{Therapeutic Potential and Sources of MSCs}

MSCs, specifically multipotent stem cells, have the capability to generate adipogenic, chondrogenic, osteogenic, and myogenic as well as endothelial cell lineages $[14,37]$. Because of these possibilities, there has been an increased focus on the isolation of MSCs from different sources for transplantation and tissue engineering. MSCs have been isolated from diverse adult-derived sources such as BM, AT, lung, heart, peripheral blood, synovium skeletal muscle, dermis, and dental pulp as well as from fetal or neonatal tissues such as amniotic fluid and membrane, placenta, UCB, cord vein, WJ, and umbilical cord [59, 105-108]. BM is a bountiful source of MSCs; however, AT is a reliable source of MSCs with the best frequency, and UCB seems to be a remarkable alternative source that allows expansion for a greater number of MSCs [59, 64, 67]. 
TABLE 6: Preclinical studies with MSCs.

\begin{tabular}{|c|c|c|c|c|}
\hline Cell source & Cell type & Pathology & Outcome & Reference \\
\hline Rat & Human AD-MSC & Peripheral nerve injury & Repair of nerve & [119] \\
\hline Rat & Human AD-MSC & Cerebral ischemia & Repair of nerve & {$[120]$} \\
\hline Mouse & Human UCB-MSC & Hind limb ischemia & Repair of artery & {$[121]$} \\
\hline Rat & Human UCB-MSC & Cavernosal nerve injury & Improved function & {$[122]$} \\
\hline Rat & Allogenic AD-MSC & Peripheral nerve injury & Repair of nerve & [123] \\
\hline Rat & Allogenic BM-MSC & Skin wound & Repair of skin & {$[124]$} \\
\hline Rat & Autologous BM-MSC & Spinal cord injury & Repair of nerve & {$[125]$} \\
\hline Rat & Autologous AD-MSC & Spinal cord injury & Repair of nerve & [126] \\
\hline Rat & Mouse SC-MSC & Erectile dysfunction & Improved function & [127] \\
\hline Rabbit & Human AD-MSC & Spinal cord injury & Repair of nerve & [128] \\
\hline Rabbit & Human UCWJ-MSC & Normal & No immune rejection & [129] \\
\hline Rabbit & Porcine S-MSC & Osteochondral defect & Immune rejection & {$[130]$} \\
\hline Rabbit & Allogenic S-MSC & Articular cartilage defect & Repair of defect & {$[131]$} \\
\hline Rabbit & Allogenic BM-MSC & Articular cartilage defect & Repair of defect & [132] \\
\hline Rabbit & Allogenic/autologous BM-MSC & Bone defect & Repair of defect & [133] \\
\hline Porcine & Autologous BM-MSC & Articular cartilage defect & Repair of defect & [134] \\
\hline Porcine & Mouse BM-CMSC & Vocal fold wound & Repair of vocal fold & [135] \\
\hline Porcine & Allogenic S-MSC & Articular cartilage defect & Repair of defect & {$[136]$} \\
\hline Canine & Allogenic BM-MSC & Bone defect & Repair of defect & [137] \\
\hline Canine & Allogenic BM-MSC & Cardiac ischemia & Improved function & {$[138]$} \\
\hline Canine & Allogenic BM-MSC & Myocardial infarction & Improved function & [139] \\
\hline Canine & Allogenic BM-MSC & Skin wound & Repair of skin & {$[140]$} \\
\hline Canine & Allogenic BM-MSC & Normal & $\begin{array}{l}\text { Inflammation, tubular necrosis, } \\
\text { mineralization, and fibrosis of kidney }\end{array}$ & {$[141]$} \\
\hline Canine & Allogenic AD-MSC & Spinal cord injury & Repair of nerve & {$[80]$} \\
\hline Canine & Allogenic UCB-MSC & Spinal cord injury & Repair of nerve & {$[84]$} \\
\hline Canine & Autologous BM-MSC & Disc degeneration & Repair of nerve & {$[142,143]$} \\
\hline Canine & Autologous BM-MSC & Bone defect & Repair of defect & {$[144]$} \\
\hline Canine & Autologous BM-MSC & Static nerve injury & Repair of nerve & [145] \\
\hline Canine & Autologous BM-MSC & Osteochondral defect & Repair of defect & {$[146]$} \\
\hline Canine & Autologous BM-MSC & Myocardial infarction & Improved function & {$[147]$} \\
\hline Canine & Autologous BM-MSC & Osteonecrosis of the femoral head & Repair of blood vessel & {$[148]$} \\
\hline Canine & Autologous BM-MSC & Oral ulcer & Repair of ulcer & [149] \\
\hline Canine & Autologous BM-MSC & Diabetes & Improved function & {$[150]$} \\
\hline Canine & Autologous BM-MSC & Vocal fold wound & Repair of vocal fold & {$[151,152]$} \\
\hline Canine & Autologous BM-MSC & Periodontal defect & Repair of defect & {$[153]$} \\
\hline Canine & Autologous BM-MSC & Periodontal class II furcation defect & Repair of defect & {$[154]$} \\
\hline Canine & Allogenic/autologous BM-MSC & Spinal cord injury & Repair of nerve & {$[155]$} \\
\hline Canine & Autologous AD-MSC & Spinal cord injury & Repair of nerve & {$[156]$} \\
\hline Canine & Autologous MSC & Chondral defect & Repair of defect & [157] \\
\hline Canine & Allogenic AD-MSC & Thoracolumbar intervertebral disc disease & Improved clinical sign & {$[158]$} \\
\hline Equine & Allogenic AD-MSC & Superficial digital flexor tendonitis & Repair of tendonitis & [159] \\
\hline Equine & Autologous BM-MSC & Superficial digital flexor tendonitis & Repair of tendonitis & {$[160]$} \\
\hline Equine & Autologous BM-MSC & Osteoarthritis & Repair of osteoarthritis & {$[161]$} \\
\hline Equine & Allogenic/autologous BM-MSC & Normal & Enhancement of MSC & {$[162]$} \\
\hline Dolphin & Autologous AD-MSC & Normal & Cell collection success & {$[163]$} \\
\hline Caprine & Autologous BM-MSC & Osteoarthritis & Repair of osteoarthritis & [164] \\
\hline
\end{tabular}

AT-MSC: adipose tissue-derived mesenchymal stem cells; UCB-MSC: umbilical cord blood-derived mesenchymal stem cells; BM-MSC: bone marrow-derived mesenchymal stem cells; SC-MSC: skeletal muscle-derived mesenchymal stem cells; S-MSC: synovium-derived mesenchymal stem cells; UCWJ-MSC: umbilical cord Wharton's jelly-derived mesenchymal stem cells. 
TABLE 7: Veterinary clinical studies with MSCs.

\begin{tabular}{|c|c|c|c|c|}
\hline Cell source & Cell type & Pathology & Outcome & Reference \\
\hline Canine & Autologous BM-MSC & Gastrocnemius tendon injury & Repair of tendon & {$[165]$} \\
\hline Canine & Autologous BM-MSC & Chronic Chagas cardiomyopathy & Improved function & {$[166]$} \\
\hline Canine & Autologous AD-MSC & Chronic anconitis & Repair of anconitis & {$[95]$} \\
\hline Canine & Autologous AD-MSC & Arthritis, patella luxation & Repair of arthritis & {$[167]$} \\
\hline Canine & Autologous AD-MSC & Chronic arthritis of hip joint & Repair of arthritis & {$[168]$} \\
\hline Canine & Autologous AD-MSC & Atopic dermatitis & Repair of dermatitis & [169] \\
\hline Canine & Allogenic AD-MSC & Lumber herniated intervertebral disc & Repair of nerve & {$[170]$} \\
\hline Canine & Allogenic AD-MSC & Hip dysplasia & Improved function & [9] \\
\hline Canine & Autologous AD-MSC & $\begin{array}{l}\text { Chronic osteoarthritis related to } \\
\text { hip dysplasia }\end{array}$ & Reduced lameness & {$[171]$} \\
\hline Canine & Autologous AD-MSC & Severe osteoarthritis & Reduced lameness & {$[172]$} \\
\hline Canine & Human ESC-MSC & Anal furunculosis & Recovery of fistulas & [173] \\
\hline Feline & Autologous AD-MSC & Chronic kidney disease & Moderate improvement in GFR & {$[174]$} \\
\hline Feline & Allogenic AD-MSC & Chronic kidney disease & Modest improvement in renal function & {$[175]$} \\
\hline Feline & Allogenic AD-MSC & Chronic kidney disease & No adverse effect & {$[176]$} \\
\hline Feline & Autologous AD-MSC & Chronic gingivostomatitis & $\begin{array}{l}\text { Reduction in the severity of } \\
\text { clinical disease }\end{array}$ & {$[177]$} \\
\hline Equine & Allogenic UCB-MSC & Chronic laminitis & Repair of laminitis & [178] \\
\hline Equine & Autologous BM-MSC & Tendon injury & Repair of tendon & [179] \\
\hline Equine & Autologous BM-MSC & Superficial digital flexor tendon & Repair of tendon & {$[180]$} \\
\hline Equine & Autologous BM-MSC & Tendinitis, desmitis & Repair of inflammation & [181] \\
\hline Equine & Autologous AD-MSC & Bone spavin & $\begin{array}{l}\text { Improvement in inflammatory } \\
\text { reaction and clinical conditions }\end{array}$ & {$[182]$} \\
\hline Equine & Allogenic AD-MSC & Endometriosis & $\begin{array}{l}\text { Positive remodeling of } \\
\text { endometrial tissue }\end{array}$ & {$[183]$} \\
\hline Equine & Allogenic AD-MSC and PRP & Superficial digital flexor tendon & Repair of tendonitis & {$[184]$} \\
\hline Equine & Allogenic AD-MSC and PRP & Tendonitis & Improved function & {$[185]$} \\
\hline Dolphin & Autologous AD/BM-MSC & Skin wound & Repair of skin & {$[186]$} \\
\hline
\end{tabular}

AT-MSC: adipose tissue-derived mesenchymal stem cells; UCB-MSC: umbilical cord blood-derived mesenchymal stem cells; BM-MSC: bone marrow-derived mesenchymal stem cells; ESC-MSC: embryonic stem cell-derived mesenchymal stem cells; GFR: glomerular filtration rate; PRP: platelet-rich plasma.

\section{UCB-MSCs from Human Sources}

The frequency of MSCs in hUCB is a point of controversy among researchers $[56,57,107]$. This is attributed to the persistent difficulties in the isolation of UCB-MSCs. Most researchers have adopted suitable conditions from the literature to enrich the recovery of UCB-MSCs, including choosing full-term UCB units, storing for no more than $15 \mathrm{~h}$, and obtaining an MNC count above $1 \times 10^{8}$ as the selection criterion for UCB units [37]. While Rebelatto et al. declared that sample volume did not correlate with MSC isolation [62], others have suggested that sample volume (minimum $33 \mathrm{~mL}$ [37] or $45 \mathrm{~mL}$ [109]) is a critical parameter. The enrichment rate of MSCs has varied broadly from $10 \%$ to $60 \%$ [110-112]. Namely, of 644 UCB units were subjected to MSC isolation in diverse studies, only 167 successful outgrowths have been recorded (26\% success rate) [38, 58-60, $62,113]$. A high enrichment rate of $90 \%$ MSCs was obtained when the UCB volume was more than $80 \mathrm{~mL}[66,70]$.

Many groups have reported an isolation efficiency of $65 \%$ using numerous culture methods such as reduction of monocytes and lymphocytes from MNCs before cell seeding, development of cells under hypoxia, and the inclusion of cytokines, platelet lysate, or medium supplements $[64,66,114,115]$. Other published studies accomplished isolation of MSCs from human UCB with up to $40-90 \%$ efficiency by adopting different parameters $[20,37$, $65-67,69,72]$. Table 8 represents the yield rate of UCBMSCs isolated from human and animal sources fulfilling special criteria.

\section{UCB-MSCs from Animal Sources}

Successful isolation of MSCs (up to 100\%) from equine UCB has been reported with the use of special culture media with a large volume of 42-250 $\mathrm{mL}[77,78]$. Although the isolation of MSCs from sheep and goat was successful, the researchers did not reveal any specific parameters that resulted in an effective number of MSCs [75, 76, 85]. Based on our literature survey, we have demonstrated that a large volume of UCB with some other special determinants is a principal factor to achieve high MSC yield. As the blood volume of cUCB is too low to yield an efficient number of MSCs, cUCB may be recognized as an unsuitable source of MSCs. Lim et al. 
TABLE 8: Yield rate of UCB-MSC isolation from human and equine fulfilling special criteria.

\begin{tabular}{|c|c|c|c|}
\hline $\begin{array}{l}\text { Source of } \\
\text { UCB }\end{array}$ & Parameters & Yield rate (\%) & Reference \\
\hline Human & Explant method & 40 & [69] \\
\hline Human & $\begin{array}{l}\text { Large BV with HPL } \\
\text { medium }\end{array}$ & 46 & {$[20]$} \\
\hline Human & $\begin{array}{l}\text { Large number of UCB } \\
\text { units }\end{array}$ & 50 & [67] \\
\hline Human & $\begin{array}{c}\text { Large BV with MesenCult } \\
\text { Proliferation kit }\end{array}$ & 60 & {$[71]$} \\
\hline Human & $\begin{aligned} \mathrm{ST} & \leq 15 \mathrm{~h}, \mathrm{BV} \geq 33 \mathrm{~mL} \\
& \geq 10^{8} \mathrm{MNC} \text { count }\end{aligned}$ & 63 & [37] \\
\hline Human & $\begin{array}{l}\text { Large number of UCB } \\
\text { units with serum-free } \\
\text { culture medium }\end{array}$ & 75 & {$[72]$} \\
\hline Human & $\begin{array}{c}\text { Factorial experiment with } \\
\text { large BV }\end{array}$ & $\geq 90$ & {$[66]$} \\
\hline Human & $\mathrm{ST} \leq 2 \mathrm{~h}, \mathrm{~V} \geq 90$ & 90.9 & {$[65]$} \\
\hline Human & $\begin{array}{c}\mathrm{DP} \leq 37 \text { weeks, } \\
\mathrm{BV} \geq 80 \mathrm{~mL}, \mathrm{ST} \leq 6 \mathrm{~h}\end{array}$ & 90 & [70] \\
\hline \multirow{3}{*}{ Equine } & PEQ medium & 100 & \\
\hline & BV $42 \mathrm{~mL} \quad$ FUD medium & 60 & [77] \\
\hline & FD medium & 20 & \\
\hline Equine & Large BV & 57 & {$[78]$} \\
\hline
\end{tabular}

HPL: human platelet lysate; MNC: mononucleated cell; ST: storage time; BV: blood volume; DP: duration of pregnancy; PEQ: PrepaCyte ${ }^{\circledR}-\mathrm{EQ}$ medium; FUD: Ficoll-Paque ${ }^{\mathrm{TM}}$ PREMIUM medium loaded with undiluted whole blood, FD: Ficoll-Paque PREMIUM medium loaded with diluted whole blood.

worked with a $58 \mathrm{~kg}$ mongrel dog, which very rarely have more than $8 \mathrm{~mL}$ of UCB [84]. In two independent studies by Kang et al. and Jang et al., UCB from multiple dogs was collected to obtain the desired number of MSCs [80, 83]. As the amount of UCB from canine cannot produce a sufficient number of MSCs, another researcher collected blood from the canine fetal heart and successfully obtained MSCs [82], which creates an inconsistency and ethical problems in the pursuit of animal experiments. Our attempt to isolate MSCs from the umbilical cord (Figure 1) [116] of three healthy dogs resulted in an average sample volume of $1 \mathrm{~mL}$ and a yield rate of $66 \%$ (unpublished data).

\section{UCB from Companion Animals}

Nowadays, canine cesarean sections (C-sections) are decreasing because of the increase in spaying or castration to prevent the birth of unwanted litters, extend longevity and promote pet health, and possibly mitigate undesirable behaviors. More precisely, spaying can help prevent uterine infections and breast tumors. Concurrently, castration of male companion animals precludes testicular cancer as well as some prostate problems. The traditional time for neutering is before the onset of sexual maturity, as long as the animal is healthy. Spaying involves abdominal surgery to remove the ovaries

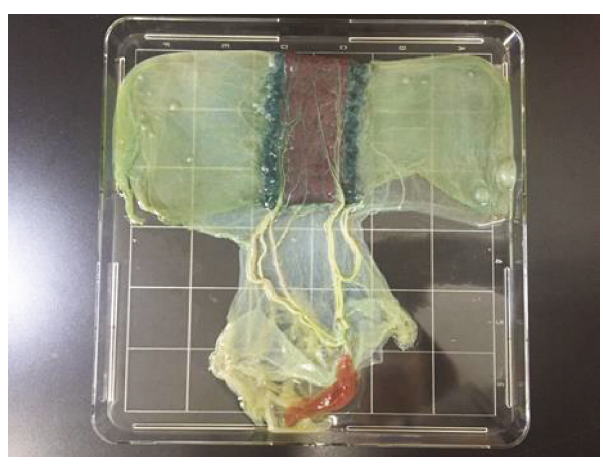

Figure 1: The canine umbilical cord with the placenta and amniotic sac.

and uterus, whereas castration involves elimination of the testes, resulting in infertility. Under these circumstances, while acquiring $\mathrm{CUCB}$ is normally challenging, these removed reproductive organs are frequently accessible in veterinary clinics. Specifically, the ovaries and testes are often discarded as medical waste but are proven to be potent and reliable sources of MSCs. MSCs from these reproductive organs (testis and ovary with adjacent portions) with high differentiation potentiality have already gained popularity.

These MSCs are able to differentiate into three mesodermal cell types, including adipogenic, osteogenic, and chondrogenic, indicating multipotent properties resembling those of AT-MSCs [117]. We can thoroughly examine the presence of MSCs in canine reproductive organs and surrounding tissues (fat and connective tissue) discarded during neutering operations; these MSCs also exhibit growth characteristics indistinguishable from those of AT-MSCs. Therefore, further investigation of canine reproductive organs and tissues with the assistance of new preservation technology [118] will improve our understanding of reproductive stem cell biology to potentially augment cell-based therapies and regenerative medicine.

Unlike in humans, it is almost impossible to obtain UCB from canine immediately after natural birth, as the dam's instinct prompts her to ingest the puppy's placenta and umbilical cord. From this perspective, we have made many efforts (unpublished data) to collect cUCB from Korean veterinary clinics. However, this was difficult, as many pet owners tend to prevent their pet from breeding. Conversely, if the canine pet is pregnant, the owner generally prefers natural birth unless a medical reason necessitates C-section. Therefore, the reduction in canine $\mathrm{C}$-sections in veterinary hospitals, the introduction of specialized breeders, and changes in the supply of canine make it almost impossible to obtain UCB from canine. Conducting a surgical procedure or C-section in canine solely to obtain UCB for laboratory purposes gives rise to the question of legitimacy. To solve this problem, we can use MSCs from canine AT [95] along with reproductive tissue. It has been demonstrated that MSCs from AT have higher frequency and potentiality compared with UCB-MSCs $[59,67]$. 


\section{Conclusions}

One challenge in cellular therapy and regenerative medicine is the availability of alternative stem cell sources. Although cUCB-MSCs can proliferate and differentiate as stem cells, cUCB is not an ideal source because of low volume and ethical considerations of using a companion animal. In this regard, we suggest broadening the investigation of canine reproductive tissue and $\mathrm{AT}$, instead of $\mathrm{UCB}$, as the preferred source of MSCs.

\section{Conflicts of Interest}

The authors declare that there is no conflict of interest regarding the publication of this paper.

\section{Authors' Contributions}

Tania Sultana and Soojung Lee contributed equally to this work and should be considered co-first authors.

\section{Acknowledgments}

This work was supported by a Basic Science Research Program through the National Research Foundation of Korea (NRF) funded by the Ministry of Education, Science and Technology (2015R1D1A1A09057348). The authors wish to thank Regeniks Co., Ltd. and the program of senior experienced researchers of Korea Industrial Technology Association (KOITA).

\section{References}

[1] P. Y. Collart-Dutilleul, F. Chaubron, J. de Vos, and F. J. Cuisinier, "Allogenic banking of dental pulp stem cells for innovative therapeutics," World Journal of Stem Cells, vol. 7, no. 7, pp. 1010-1021, 2015.

[2] C. D. Porada and G. Almeida-Porada, "Mesenchymal stem cells as therapeutics and vehicles for gene and drug delivery," Advanced Drug Delivery Reviews, vol. 62, no. 12, pp. 11561166, 2010.

[3] S. W. Lane, D. A. Williams, and F. M. Watt, "Modulating the stem cell niche for tissue regeneration," Nature Biotechnology, vol. 32, no. 8, pp. 795-803, 2014.

[4] D. Drago, C. Cossetti, N. Iraci et al., "The stem cell secretome and its role in brain repair," Biochimie, vol. 95, no. 12, pp. 2271-2285, 2013.

[5] S. W. Volk and C. Theoret, "Translating stem cell therapies: the role of companion animals in regenerative medicine," Wound Repair and Regeneration, vol. 21, no. 3, pp. 382394, 2013.

[6] M. M. Dehghan, M. Baghaban Eslaminejad, N. Motallebizadeh et al., "Transplantation of autologous bone marrow mesenchymal stem cells with platelet-rich plasma accelerate distraction osteogenesis in a canine model," Cell Journal, vol. 17, no. 2, pp. 243-252, 2015.

[7] L. da Silva Meirelles, P. C. Chagastelles, and N. B. Nardi, "Mesenchymal stem cells reside in virtually all post-natal organs and tissues," Journal of Cell Science, vol. 119, no. 11, pp. 2204-2213, 2006.
[8] H. J. Snippert and H. Clevers, "Tracking adult stem cells," EMBO Reports, vol. 12, no. 2, pp. 113-122, 2011.

[9] C. Marx, M. D. Silveira, I. Selbach et al., "Acupoint injection of autologous stromal vascular fraction and allogeneic adipose-derived stem cells to treat hip dysplasia in dogs," Stem Cells International, vol. 2014, Article ID 391274, 6 pages, 2014.

[10] P. Torricelli, M. Fini, G. Filardo et al., "Regenerative medicine for the treatment of musculoskeletal overuse injuries in competition horses," International Orthopaedics, vol. 35 , no. 10, pp. 1569-1576, 2011.

[11] D. J. Prockop, "Marrow stromal cells as stem cells for nonhematopoietic tissues," Science, vol. 276, no. 5309, pp. 71-74, 1997.

[12] A. I. Caplan, "Adult mesenchymal stem cells for tissue engineering versus regenerative medicine," Journal of Cellular Physiology, vol. 213, no. 2, pp. 341-347, 2007.

[13] Y. Jiang, B. N. Jahagirdar, R. L. Reinhardt et al., "Pluripotency of mesenchymal stem cells derived from adult marrow," Nature, vol. 418, no. 6893, pp. 41-49, 2002.

[14] B. M. Abdallah and M. Kassem, "Human mesenchymal stem cells: from basic biology to clinical applications," Gene Therapy, vol. 15, no. 2, pp. 109-116, 2008.

[15] R. A. Panepucci, J. L. C. Siufi, W. A. Silva Jr et al., "Comparison of gene expression of umbilical cord vein and bone marrow-derived mesenchymal stem cells," Stem Cells, vol. 22, no. 7, pp. 1263-1278, 2004.

[16] J. A. Jeong, S. H. Hong, E. J. Gang et al., "Differential gene expression profiling of human umbilical cord blood-derived mesenchymal stem cells by DNA microarray," Stem Cells, vol. 23, no. 4, pp. 584-593, 2005.

[17] X. Wei, X. Yang, Z. P. Han, F. F. Qu, L. Shao, and Y. F. Shi, "Mesenchymal stem cells: a new trend for cell therapy," Acta Pharmacologica Sinica, vol. 34, no. 6, pp. 747-754, 2013.

[18] D. C. Ding, Y. H. Chang, W. C. Shyu, and S. Z. Lin, "Human umbilical cord mesenchymal stem cells: a new era for stem cell therapy," Cell Transplantation, vol. 24, no. 3, pp. 339$347,2015$.

[19] M. W. Lee, M. S. Yang, J. S. Park, H. C. Kim, Y. J. Kim, and J. Choi, "Isolation of mesenchymal stem cells from cryopreserved human umbilical cord blood," International Journal of Hematology, vol. 81, no. 2, pp. 126-130, 2005.

[20] A. Reinisch, C. Bartmann, E. Rohde et al., "Humanized system to propagate cord blood-derived multipotent mesenchymal stromal cells for clinical application," Regenerative Medicine, vol. 2, no. 4, pp. 371-382, 2007.

[21] A. Bartholomew, C. Sturgeon, M. Siatskas et al., "Mesenchymal stem cells suppress lymphocyte proliferation in vitro and prolong skin graft survival in vivo," Experimental Hematology, vol. 30, no. 1, pp. 42-48, 2002.

[22] R. Cui, H. Rekasi, M. Hepner-Schefczyk et al., "Human mesenchymal stromal/stem cells acquire immunostimulatory capacity upon cross-talk with natural killer cells and might improve the NK cell function of immunocompromised patients," Stem Cell Research \& Therapy, vol. 7, no. 1, p. 88, 2016.

[23] A. J. Friedenstein, I. I. Piatetzky-Shapiro, and K. V. Petrakova, "Osteogenesis in transplants of bone marrow cells," Development, vol. 16, no. 3, pp. 381-390, 1966.

[24] U. R. Goessler, P. Bugert, K. Bieback et al., "In-vitro analysis of the expression of TGFbeta-superfamily-members during 
chondrogenic differentiation of mesenchymal stem cells and chondrocytes during dedifferentiation in cell culture," Cellular \& Molecular Biology Letters, vol. 10, no. 2, pp. 345-362, 2005.

[25] X. Q. Kang, W. J. Zang, T. S. Song et al., "Rat bone marrow mesenchymal stem cells differentiate into hepatocytes in vitro," World Journal of Gastroenterology, vol. 11, no. 22, pp. 3479-3484, 2005.

[26] M. K. Majumdar, M. A. Thiede, J. D. Mosca, M. Moorman, and S. L. Gerson, "Phenotypic and functional comparison of cultures of marrow-derived mesenchymal stem cells (MSCs) and stromal cells," Journal of Cellular Physiology, vol. 176, no. 1, pp. 57-66, 1998.

[27] D. Orlic, "Adult bone marrow stem cells regenerate myocardium in ischemic heart disease," Annals of the New York Academy of Sciences, vol. 996, no. 1, pp. 152-157, 2003.

[28] R. E. Schwartz, M. Reyes, L. Koodie et al., "Multipotent adult progenitor cells from bone marrow differentiate into functional hepatocyte-like cells," The Journal of Clinical Investigation, vol. 109, no. 10, pp. 1291-1302, 2002.

[29] J. Chagraoui, A. Lepage-Noll, A. Anjo, G. Uzan, and P. Charbord, "Fetal liver stroma consists of cells in epithelial-to-mesenchymal transition," Blood, vol. 101, no. 8, pp. 2973-2982, 2003.

[30] G. Kögler, S. Sensken, J. A. Airey et al., "A new human somatic stem cell from placental cord blood with intrinsic pluripotent differentiation potential," The Journal of Experimental Medicine, vol. 200, no. 2, pp. 123-135, 2004.

[31] M. Ayat Elahi, M. Kabir Salmani, M. Soleymani et al., "Expansion of human marrow derived mesenchymal stem cells and their transdifferentiation potential," Iranian Red Crescent Medical Journal, vol. 12, no. 4, pp. 446-452, 2010.

[32] S. M. Watt and M. Contreras, "Stem cell medicine: umbilical cord blood and its stem cell potential," Seminars in Fetal \& Neonatal Medicine, vol. 10, no. 3, pp. 209-220, 2005.

[33] M. F. Pittenger, A. M. Mackay, S. C. Beck et al., "Multilineage potential of adult human mesenchymal stem cells," Science, vol. 284, no. 5411, pp. 143-147, 1999.

[34] M. Aoki, M. Yasutake, and T. Murohara, "Derivation of functional endothelial progenitor cells from human umbilical cord blood mononuclear cells isolated by a novel cell filtration device," Stem Cells, vol. 22, no. 6, pp. 994-1002, 2004.

[35] K. A. Jackson, S. M. Majka, H. Wang et al., "Regeneration of ischemic cardiac muscle and vascular endothelium by adult stem cells," The Journal of Clinical Investigation, vol. 107, no. 11, pp. 1395-1402, 2001.

[36] P. A. Zuk, M. Zhu, H. Mizuno et al., "Multilineage cells from human adipose tissue: implications for cell-based therapies," Tissue Engineering, vol. 7, no. 2, pp. 211-228, 2001.

[37] K. Bieback, S. Kern, H. Klüter, and H. Eichler, "Critical parameters for the isolation of mesenchymal stem cells from umbilical cord blood," Stem Cells, vol. 22, no. 4, pp. 625-634, 2004.

[38] A. Erices, P. Conget, and J. J. Minguell, "Mesenchymal progenitor cells in human umbilical cord blood," British Journal of Haematology, vol. 109, no. 1, pp. 235-242, 2000.

[39] H. S. Goodwin, A. R. Bicknese, S. N. Chien et al., "Multilineage differentiation activity by cells isolated from umbilical cord blood: expression of bone, fat, and neural markers," Biology of Blood and Marrow Transplantation, vol. 7, no. 11, pp. 581-588, 2001.
[40] E. M. Horwitz, D. J. Prockop, L. A. Fitzpatrick et al., "Transplantability and therapeutic effects of bone marrowderived mesenchymal cells in children with osteogenesis imperfecta," Nature Medicine, vol. 5, no. 3, pp. 309-313, 1999.

[41] G. D'Ippolito, P. C. Schiller, C. Ricordi, B. A. Roos, and G. A. Howard, "Age-related osteogenic potential of mesenchymal stromal stem cells from human vertebral bone marrow," Journal of Bone and Mineral Research, vol. 14, no. 7, pp. 1115-1122, 1999.

[42] S. M. Mueller and J. Glowacki, "Age-related decline in the osteogenic potential of human bone marrow cells cultured in three-dimensional collagen sponges," Journal of Cellular Biochemistry, vol. 82, no. 4, pp. 583-590, 2001.

[43] K. Stenderup, J. Justesen, C. Clausen, and M. Kassem, “Aging is associated with decreased maximal life span and accelerated senescence of bone marrow stromal cells," Bone, vol. 33, no. 6, pp. 919-926, 2003.

[44] L. W. Wu, Y. L. Wang, J. M. Christensen et al., "Donor age negatively affects the immunoregulatory properties of both adipose and bone marrow derived mesenchymal stem cells," Transplant Immunology, vol. 30, no. 4, pp. 122-127, 2014.

[45] V. D. Roobrouck, F. Ulloa-Montoya, and C. M. Verfaillie, "Self-renewal and differentiation capacity of young and aged stem cells," Experimental Cell Research, vol. 314, no. 9, pp. 1937-1944, 2008.

[46] H. Alves, J. van Ginkel, N. Groen et al., "A mesenchymal stromal cell gene signature for donor age," PLoS One, vol. 7, no. 8, article e42908, 2012.

[47] E. J. Gang, S. H. Hong, J. A. Jeong et al., "In vitro mesengenic potential of human umbilical cord blood-derived mesenchymal stem cells," Biochemical and Biophysical Research Communications, vol. 321, no. 1, pp. 102-108, 2004.

[48] M. Di Nicola, C. Carlo-Stella, M. Magni et al., "Human bone marrow stromal cells suppress T-lymphocyte proliferation induced by cellular or nonspecific mitogenic stimuli," Blood, vol. 99, no. 10, pp. 3838-3843, 2002.

[49] K. Le Blanc, C. Tammik, K. Rosendahl, E. Zetterberg, and O. Ringdén, "HLA expression and immunologic properties of differentiated and undifferentiated mesenchymal stem cells," Experimental Hematology, vol. 31, no. 10, pp. 890896, 2003.

[50] S.-U. Kuh, Y. E. Cho, D. H. Yoon, K. N. Kim, and Y. Ha, "Functional recovery after human umbilical cord blood cells transplantation with brain-derived neutrophic factor into the spinal cord injured rat," Acta Neurochirurgica, vol. 147, no. 9, pp. 985-992, 2005.

[51] S. S. Grewal, J. N. Barker, S. M. Davies, and J. E. Wagner, "Unrelated donor hematopoietic cell transplantation: marrow or umbilical cord blood?," Blood, vol. 101, no. 11, pp. 4233-4244, 2003.

[52] J. M. Hows, "Status of umbilical cord blood transplantation in the year 2001," Journal of Clinical Pathology, vol. 54, no. 6, pp. 428-434, 2001.

[53] H. E. Broxmeyer, G. W. Douglas, G. Hangoc et al., "Human umbilical cord blood as a potential source of transplantable hematopoietic stem/progenitor cells," Proceedings of the National Academy of Sciences of the United States of America, vol. 86, no. 10, pp. 3828-3832, 1989. 
[54] R. Huss, "Isolation of primary and immortalized CD $34^{-}$ hematopoietic and mesenchymal stem cells from various sources," Stem Cells, vol. 18, no. 1, pp. 1-9, 2000.

[55] M. Gutierrez-Rodriguez, E. Reyes-Maldonado, and H. Mayani, "Characterization of the adherent cells developed in Dexter-type long-term cultures from human umbilical cord blood," Stem Cells, vol. 18, no. 1, pp. 46-52, 2000.

[56] K. Mareschi, E. Biasin, W. Piacibello, M. Aglietta, E. Madon, and F. Fagioli, "Isolation of human mesenchymal stem cells: bone marrow versus umbilical cord blood," Haematology, vol. 86, no. 10, pp. 1099-1100, 2001.

[57] S. A. Wexler, C. Donaldson, P. Denning-Kendall, C. Rice, B. Bradley, and J. M. Hows, "Adult bone marrow is a rich source of human mesenchymal 'stem' cells but umbilical cord and mobilized adult blood are not," British Journal of Haematology, vol. 121, no. 2, pp. 368-374, 2003.

[58] W. Wagner, F. Wein, A. Seckinger et al., "Comparative characteristics of mesenchymal stem cells from human bone marrow, adipose tissue, and umbilical cord blood," Experimental Hematology, vol. 33, no. 11, pp. 1402-1416, 2005.

[59] S. Kern, H. Eichler, J. Stoeve, H. Klüter, and K. Bieback, "Comparative analysis of mesenchymal stem cells from bone marrow, umbilical cord blood, or adipose tissue," Stem Cells, vol. 24, no. 5, pp. 1294-1301, 2006.

[60] S. E. Yang, C. W. Ha, M. H. Jung et al., "Mesenchymal stem/ progenitor cells developed in cultures from UC blood," Cytotherapy, vol. 6, no. 5, pp. 476-486, 2004.

[61] A. A. Martins, A. Paiva, J. M. Morgado, A. Gomes, and M. L. Pais, "Quantification and immunophenotypic characterization of bone marrow and umbilical cord blood mesenchymal stem cells by multicolor flow cytometry," Transplantation Proceedings, vol. 41, no. 3, pp. 943-946, 2009.

[62] C. K. Rebelatto, A. M. Aguiar, M. P. Moretão et al., "Dissimilar differentiation of mesenchymal stem cells from bone marrow, umbilical cord blood, and adipose tissue," Experimental Biology and Medicine, vol. 233, no. 7, pp. 901-913, 2008.

[63] M. Yu, Z. Xiao, L. Shen, and L. Li, "Mid-trimester fetal bloodderived adherent cells share characteristics similar to mesenchymal stem cells but full-term umbilical cord blood does not," British Journal of Haematology, vol. 124, no. 5, pp. 666-675, 2004.

[64] O. K. Lee, T. K. Kuo, W. M. Chen, K. D. Lee, S. L. Hsieh, and T. H. Chen, "Isolation of multipotent mesenchymal stem cells from umbilical cord blood," Blood, vol. 103, no. 5, pp. 1669-1675, 2004.

[65] X. Zhang, M. Hirai, S. Cantero et al., "Isolation and characterization of mesenchymal stem cells from human umbilical cord blood: reevaluation of critical factors for successful isolation and high ability to proliferate and differentiate to chondrocytes as compared to mesenchymal stem cells from bone marrow and adipose tissue," Journal of Cellular Biochemistry, vol. 112, no. 4, pp. 1206-1218, 2011.

[66] X. Fan, T. Liu, Y. Liu, X. Ma, and Z. Cui, "Optimization of primary culture condition for mesenchymal stem cells derived from umbilical cord blood with factorial design," Biotechnology Progress, vol. 25, no. 2, pp. 499-507, 2009.

[67] H. Jin, Y. Bae, M. Kim et al., "Comparative analysis of human mesenchymal stem cells from bone marrow, adipose tissue, and umbilical cord blood as sources of cell therapy," International Journal of Molecular Sciences, vol. 14, no. 9, pp. 1798618001, 2013.
[68] A. M. Mackay, S. C. Beck, J. M. Murphy, F. P. Barry, C. O. Chichester, and M. F. Pittenger, "Chondrogenic differentiation of cultured human mesenchymal stem cells from marrow," Tissue Engineering, vol. 4, no. 4, pp. 415-428, 1998.

[69] R. Secunda, R. Vennila, A. M. Mohanashankar, M. Rajasundari, S. Jeswanth, and R. Surendran, "Isolation, expansion and characterisation of mesenchymal stem cells from human bone marrow, adipose tissue, umbilical cord blood and matrix: a comparative study," Cytotechnology, vol. 67, no. 5, pp. 793-807, 2015.

[70] T. T. Sibov, P. Severino, L. C. Marti et al., "Mesenchymal stem cells from umbilical cord blood: parameters for isolation, characterization and adipogenic differentiation," Cytotechnology, vol. 64, no. 5, pp. 511-521, 2012.

[71] A. Vasaghi, A. Dehghani, Z. Khademalhosseini, M. Khosravi Maharlooei, A. Monabati, and A. Attar, "Parameters that influence the isolation of multipotent mesenchymal stromal cells from human umbilical cord blood," Hematology/Oncology and Stem Cell Therapy, vol. 6, no. 1, pp. 1-8, 2013.

[72] C. H. Liu, M. L. Wu, and S. M. Hwang, "Optimization of serum free medium for cord blood mesenchymal stem cells," Biochemical Engineering Journal, vol. 33, no. 1, pp. 1-9, 2007.

[73] J. Jones, C. E. Stevens, P. Rubinstein, R. R. Robertazzi, A. Kerr, and M. F. Cabbad, "Obstetric predictors of placental/umbilical cord blood volume for transplantation," American Journal of Obstetrics and Gynecology, vol. 188, no. 2, pp. 503-509, 2003.

[74] Y. Chang, C. Tseng, L. Hsu, T. Hsieh, and S. Hwang, "Characterization of two populations of mesenchymal progenitor cells in umbilical cord blood," Cell Biology International, vol. 30, no. 6, pp. 495-499, 2006.

[75] J. R. Fuchs, D. Hannouche, S. Terada, S. Zand, J. P. Vacanti, and D. O. Fauza, "Cartilage engineering from ovine umbilical cord blood mesenchymal progenitor cells," Stem Cells, vol. 23, no. 7, pp. 958-964, 2005.

[76] L. Fadel, B. R. Viana, M. L. T. Feitosa et al., "Protocols for obtainment and isolation of two mesenchymal stem cell sources in sheep," Acta Cirúrgica Brasileira, vol. 26, no. 4, pp. 267-273, 2011.

[77] T. G. Koch, P. D. Thomsen, and D. H. Betts, "Improved isolation protocol for equine cord blood-derived mesenchymal stromal cells," Cytotherapy, vol. 11, no. 4, pp. 443-447, 2009.

[78] T. G. Koch, T. Heerkens, P. D. Thomsen, and D. H. Betts, "Isolation of mesenchymal stem cells from equine umbilical cord blood," BMC Biotechnology, vol. 7, no. 1, p. 26, 2007.

[79] S. A. Reed and S. E. Johnson, "Refinement of culture conditions for maintenance of undifferentiated equine umbilical cord blood stem cells," Journal of Equine Veterinary Science, vol. 32, no. 6, pp. 360-366, 2012.

[80] B.-J. Kang, H. H. Ryu, S. S. Park et al., "Comparing the osteogenic potential of canine mesenchymal stem cells derived from adipose tissues, bone marrow, umbilical cord blood, and Wharton's jelly for treating bone defects," Journal of Veterinary Science, vol. 13, no. 3, pp. 299-310, 2012.

[81] Y. E. Byeon, H. H. Ryu, S. S. Park et al., "Paracrine effect of canine allogenic umbilical cord blood-derived mesenchymal stromal cells mixed with beta-tricalcium phosphate on bone regeneration in ectopic implantations," Cytotherapy, vol. 12, no. 5, pp. 626-636, 2010.

[82] M.-S. Seo, Y. H. Jeong, J. R. Park et al., "Isolation and characterization of canine umbilical cord blood-derived 
mesenchymal stem cells," Journal of Veterinary Science, vol. 10, no. 3, pp. 181-187, 2009.

[83] B.-J. Jang, Y. E. Byeon, J. H. Lim et al., "Implantation of canine umbilical cord blood-derived mesenchymal stem cells mixed with beta-tricalcium phosphate enhances osteogenesis in bone defect model dogs," Journal of Veterinary Science, vol. 9, no. 4, pp. 387-393, 2008.

[84] J.-H. Lim, Y. E. Byeon, H. H. Ryu et al., “Transplantation of canine umbilical cord blood-derived mesenchymal stem cells in experimentally induced spinal cord injured dogs," Journal of Veterinary Science, vol. 8, no. 3, pp. 275-282, 2007.

[85] G. R. Martins, R. C. Marinho, R. Q. Bezerra-Junior, L. M. C. Câmara, L. C. Albuquerque-Pinto, and M. F. S. Teixeira, "Isolation, culture and characterization of multipotent mesenchymal stem cells from goat umbilical cord blood," Pesquisa Veterinária Brasileira, vol. 37, no. 6, pp. 643-649, 2017.

[86] L. Galuppo, "Stem cells and regenerative medicines in horsesprogress through 2010," CEH Horse Report, vol. 28, pp. 2-19, 2010.

[87] E. Gluckman, H. E. Broxmeyer, A. D. Auerbach et al., "Hematopoietic reconstitution in a patient with Fanconi's anemia by means of umbilical-cord blood from an HLAidentical sibling," The New England Journal of Medicine, vol. 321, no. 17, pp. 1174-1178, 1989.

[88] E. Gluckman, V. Rocha, A. Boyer-Chammard et al., "Outcome of cord-blood transplantation from related and unrelated donors. Eurocord Transplant Group and the European Blood and Marrow Transplantation Group," The New England Journal of Medicine, vol. 337, no. 6, pp. 373381, 1997.

[89] I. S. Han, J. S. Ra, M. W. Kim et al., "Differentiation of CD34+ cells from human cord blood and murine bone marrow is suppressed by C6 $\beta$-chemokines," Molecules and Cells, vol. 15, no. 2, pp. 176-180, 2003.

[90] S. K. Kim, S. K. Koh, S. U. Song et al., "Ex vivo expansion and clonality of CD34+ selected cells from bone marrow and cord blood in a serum-free media," Molecules and Cells, vol. 14, no. 3, pp. 367-373, 2002.

[91] G. Kogler, S. Sensken, and P. Wernet, "Comparative generation and characterization of pluripotent unrestricted somatic stem cells with mesenchymal stem cells from human cord blood," Experimental Hematology, vol. 34, no. 11, pp. 15891595, 2006.

[92] S. Sensken, S. Waclawczyk, A. S. Knaupp et al., "In vitro differentiation of human cord blood-derived unrestricted somatic stem cells towards an endodermal pathway," Cytotherapy, vol. 9, no. 4, pp. 362-378, 2007.

[93] S. Greschat, J. Schira, P. Küry et al., "Unrestricted somatic stem cells from human umbilical cord blood can be differentiated into neurons with a dopaminergic phenotype," Stem Cells and Development, vol. 17, no. 2, pp. 221-232, 2008.

[94] M. Gutiérrez-Rodríguez, E. Reyes-Maldonado, and H. Mayani, "Characterization of the adherent cells developed in Dexter-type long-term cultures from human umbilical cord blood," Stem Cells, vol. 18, no. 1, pp. 46-52, 2000.

[95] A. Guercio, P. di Marco, S. Casella et al., "Production of canine mesenchymal stem cells from adipose tissue and their application in dogs with chronic osteoarthritis of the humeroradial joints," Cell Biology International, vol. 36, no. 2, pp. 189-194, 2012.
[96] J. R. Mauney, V. Volloch, and D. L. Kaplan, "Role of adult mesenchymal stem cells in bone tissue engineering applications: current status and future prospects," Tissue Engineering, vol. 11, no. 5-6, pp. 787-802, 2005.

[97] X. Wang, F. Li, and C. Niyibizi, "Progenitors systemically transplanted into neonatal mice localize to areas of active bone formation in vivo: implications of cell therapy for skeletal diseases," Stem Cells, vol. 24, no. 8, pp. 1869-1878, 2006.

[98] J. S. Guo, Y. S. Zeng, H. B. Li et al., "Cotransplant of neural stem cells and NT-3 gene modified Schwann cells promote the recovery of transected spinal cord injury," Spinal Cord, vol. 45 , no. 1, pp. 15-24, 2007.

[99] H. D. Ochs and A. J. Thrasher, "The Wiskott-Aldrich syndrome," The Journal of Allergy and Clinical Immunology, vol. 117, no. 4, pp. 725-738, 2006.

[100] J. Hipp and A. Atala, "Sources of stem cells for regenerative medicine," Stem Cell Reviews, vol. 4, no. 1, pp. 3-11, 2008.

[101] K. Orino, M. Uehara, S. Okano, and K. Watanabe, "Purification and characterization of canine serum ferritin-binding proteins," Biometals, vol. 19, no. 3, pp. 315-322, 2006.

[102] S. W. Volk, D. L. Diefenderfer, S. A. Christopher, M. E. Haskins, and P. S. Leboy, "Effects of osteogenic inducers on cultures of canine mesenchymal stem cells," American Journal of Veterinary Research, vol. 66, no. 10, pp. 17291737, 2005.

[103] W. Yang, S. Lee, J. Yoon, and J. I. Lee, "Stem cell therapy status in veterinary medicine," Journal of Tissue Engineering and Regenerative Medicine, vol. 12, no. S2, pp. 67-77, 2015.

[104] S. Lee, I. J. Jang, W. Yang et al., "Reevaluation of spontaneous and frequently diagnosed disease in companion animals and its application in tissue engineering and regenerative medicine," Journal of Tissue Engineering and Regenerative Medicine, vol. 12, no. S2, pp. 84-93, 2015.

[105] A. Malgieri, E. Kantzari, M. P. Patrizi, and S. Gambardella, "Bone marrow and umbilical cord blood human mesenchymal stem cells state of the art," International Journal of Clinical and Experimental Medicine, vol. 3, no. 4, pp. 248-269, 2010.

[106] Z. Miao, J. Jin, L. Chen et al., "Isolation of mesenchymal stem cells from human placenta: comparison with human bone marrow mesenchymal stem cells," Cell Biology International, vol. 30, no. 9, pp. 681-687, 2006.

[107] Y. A. Romanov, V. A. Svintsitskaya, and V. N. Smirnov, "Searching for alternative sources of postnatal human mesenchymal stem cells: candidate MSC-like cells from umbilical cord," Stem Cells, vol. 21, no. 1, pp. 105-110, 2003.

[108] J. Bosch, A. P. Houben, T. F. Radke et al., "Distinct differentiation potential of "MSC" derived from cord blood and umbilical cord: are cord-derived cells true mesenchymal stromal cells?," Stem Cells and Development, vol. 21, no. 11, pp. 1977-1988, 2012.

[109] R. A. Musina, E. S. Bekchanova, A. V. Belyavskii, T. S. Grinenko, and G. T. Sukhikh, "Umbilical cord blood mesenchymal stem cells," Bulletin of Experimental Biology and Medicine, vol. 143, no. 1, pp. 127-131, 2007.

[110] M. Secco, E. Zucconi, N. M. Vieira et al., "Multipotent stem cells from umbilical cord: cord is richer than blood!," Stem Cells, vol. 26, no. 1, pp. 146-150, 2008.

[111] M. A. Avanzini, M. E. Bernardo, A. M. Cometa et al., "Generation of mesenchymal stromal cells in the presence of platelet 
lysate: a phenotypic and functional comparison of umbilical cord blood- and bone marrow-derived progenitors," Haematologica, vol. 94, no. 12, pp. 1649-1660, 2009.

[112] M. Zeddou, A. Briquet, B. Relic et al., "The umbilical cord matrix is a better source of mesenchymal stem cells (MSC) than the umbilical cord blood," Cell Biology International, vol. 34, no. 7, pp. 693-701, 2010.

[113] M. F. Manca, I. Zwart, J. Beo et al., "Characterization of mesenchymal stromal cells derived from full-term umbilical cord blood," Cytotherapy, vol. 10, no. 1, pp. 54-68, 2008.

[114] A. Laitinen, J. Nystedt, and S. Laitinen, "The isolation and culture of human cord blood-derived mesenchymal stem cells under low oxygen conditions," Methods in Molecular Biology, vol. 698, pp. 63-73, 2011.

[115] F. Dos Santos, P. Z. Andrade, J. S. Boura, M. M. Abecasis, C. L. da Silva, and J. M. Cabral, "Ex vivo expansion of human mesenchymal stem cells: a more effective cell proliferation kinetics and metabolism under hypoxia," Journal of Cellular Physiology, vol. 223, no. 1, pp. 27-35, 2010.

[116] H. E. Evans and A. D. Lahunta, Miller's Anatomy of the Dog, Vol. 4, Elsevier, 4th edition, 2013.

[117] A. B. Trindade Hill, J. Therrien, J. M. Garcia, and L. C. Smith, "Mesenchymal-like stem cells in canine ovary show high differentiation potential," Cell Proliferation, vol. 50, no. 6, article e12391, 2017.

[118] T. Sultana, J. I. Lee, J. H. Park, and S. Lee, "Supercooling storage for the transplantable sources from the rat and the rabbit: a preliminary report," Transplantation Proceedings, vol. 50, no. 4, pp. 1178-1182, 2018.

[119] K. Tomita, T. Madura, Y. Sakai, K. Yano, G. Terenghi, and K. Hosokawa, "Glial differentiation of human adiposederived stem cells: implications for cell-based transplantation therapy," Neuroscience, vol. 236, pp. 55-65, 2013.

[120] S. K. Kang, D. H. Lee, Y. C. Bae, H. K. Kim, S. Y. Baik, and J. S. Jung, "Improvement of neurological deficits by intracerebral transplantation of human adipose tissue-derived stromal cells after cerebral ischemia in rats," Experimental Neurology, vol. 183, no. 2, pp. 355-366, 2003.

[121] S.-W. Kim, H. Han, G. T. Chae et al., "Successful stem cell therapy using umbilical cord blood-derived multipotent stem cells for Buerger's disease and ischemic limb disease animal model," Stem Cells, vol. 24, no. 6, pp. 1620-1626, 2006.

[122] A. Choi, S. D. Kim, D. W. Sohn et al., "The effect of human umbilical cord blood derived mesenchymal stem cell therapy in rat model of cavernosal nerve injury," Korean Journal of Andrology, vol. 26, pp. 136-141, 2008.

[123] A. J. Reid, M. Sun, M. Wiberg, S. Downes, G. Terenghi, and P. J. Kingham, "Nerve repair with adipose-derived stem cells protects dorsal root ganglia neurons from apoptosis," Neuroscience, vol. 199, pp. 515-522, 2011.

[124] L. Chen, E. E. Tredget, C. Liu, and Y. Wu, "Analysis of allogenicity of mesenchymal stem cells in engraftment and wound healing in mice," PLoS One, vol. 4, no. 9, article e7119, 2009.

[125] M. S. Pedram, M. M. Dehghan, M. Soleimani, D. Sharifi, S. H. Marjanmehr, and Z. Nasiri, "Transplantation of a combination of autologous neural differentiated and undifferentiated mesenchymal stem cells into injured spinal cord of rats," Spinal Cord, vol. 48, no. 6, pp. 457-463, 2010.

[126] S. K. Kang, M. J. Shin, J. S. Jung, Y. G. Kim, and C. H. Kim, "Autologous adipose tissue-derived stromal cells for treatment of spinal cord injury," Stem Cells and Development, vol. 15, no. 4, pp. 583-594, 2006.

[127] G. Nolazco, I. Kovanecz, D. Vernet et al., "Effect of musclederived stem cells on the restoration of corpora cavernosa smooth muscle and erectile function in the aged rat," BJU International, vol. 101, no. 9, pp. 1156-1164, 2008.

[128] H.-J. Chun, Y. S. Kim, B. K. Kim et al., "Transplantation of human adipose-derived stem cells in a rabbit model of traumatic degeneration of lumbar discs," World Neurosurgery, vol. 78, no. 3-4, pp. 364-371, 2012.

[129] S. Liu, M. Yuan, K. Hou et al., "Immune characterization of mesenchymal stem cells in human umbilical cord Wharton's jelly and derived cartilage cells," Cellular Immunology, vol. 278, no. 1-2, pp. 35-44, 2012.

[130] M. Pei, Z. Yan, M. Shoukry, and B. M. Boyce, "Failure of xenoimplantation using porcine synovium-derived stem cell-based cartilage tissue constructs for the repair of rabbit osteochondral defects," Journal of Orthopaedic Research, vol. 28, no. 8, pp. 1064-1070, 2010.

[131] J.-I. Lee, M. Sato, H. W. Kim, and J. Mochida, "Transplantation of scaffold-free spheroids composed of synoviumderived cells and chondrocytes for the treatment of cartilage defects of the knee," European Cells and Materials, vol. 22, pp. 275-290, 2011.

[132] L. X. Tay, R. E. Ahmad, H. Dashtdar et al., “Treatment outcomes of alginate-embedded allogenic mesenchymal stem cells versus autologous chondrocytes for the repair of focal articular cartilage defects in a rabbit model," The American Journal of Sports Medicine, vol. 40, no. 1, pp. 83-90, 2012.

[133] R. K. Udehiya, Amarpal, H. P. Aithal et al., "Comparison of autogenic and allogenic bone marrow derived mesenchymal stem cells for repair of segmental bone defects in rabbits," Research in Veterinary Science, vol. 94, no. 3, pp. 743-752, 2013.

[134] G. Zhou, W. Liu, L. Cui, X. Wang, T. Liu, and Y. Cao, "Repair of porcine articular osteochondral defects in nonweightbearing areas with autologous bone marrow stromal cells," Tissue Engineering, vol. 12, no. 11, pp. 3209-3221, 2006.

[135] Y.-M. Kim, T. G. Yi, J. S. Choi et al., "Bone marrow-derived clonal mesenchymal stem cells as a source of cell therapy for promoting vocal fold wound healing," The Annals of Otology, Rhinology, and Laryngology, vol. 122, no. 2, pp. 121-130, 2013.

[136] T. Nakamura, I. Sekiya, T. Muneta et al., "Arthroscopic, histological and MRI analyses of cartilage repair after a minimally invasive method of transplantation of allogeneic synovial mesenchymal stromal cells into cartilage defects in pigs," Cytotherapy, vol. 14, no. 3, pp. 327-338, 2012.

[137] T. L. Arinzeh, S. J. Peter, M. P. Archambault et al., “Allogeneic mesenchymal stem cells regenerate bone in a criticalsized canine segmental defect," The Journal of Bone and Joint Surgery-American Volume, vol. 85, no. 10, pp. 1927-1935, 2003.

[138] G. V. Silva, S. Litovsky, J. A. Assad et al., "Mesenchymal stem cells differentiate into an endothelial phenotype, enhance vascular density, and improve heart function in a canine chronic ischemia model," Circulation, vol. 111, no. 2, pp. 150-156, 2005.

[139] E. C. Perin, G. V. Silva, J. A. R. Assad et al., "Comparison of intracoronary and transendocardial delivery of allogeneic mesenchymal cells in a canine model of acute myocardial 
infarction," Journal of Molecular and Cellular Cardiology, vol. 44, no. 3, pp. 486-495, 2008.

[140] J. W. Kim, J. H. Lee, Y. S. Lyoo, D. I. Jung, and H. M. Park, "The effects of topical mesenchymal stem cell transplantation in canine experimental cutaneous wounds," Veterinary Dermatology, vol. 24, no. 2, pp. 242-e53, 2013.

[141] J.-H. Yoo, C. Park, D. I. Jung et al., "In vivo cell tracking of canine allogenic mesenchymal stem cells administration via renal arterial catheterization and physiopathological effects on the kidney in two healthy dogs," The Journal of Veterinary Medical Science, vol. 73, no. 2, pp. 269-274, 2011.

[142] A. Hiyama, J. Mochida, T. Iwashina et al., "Transplantation of mesenchymal stem cells in a canine disc degeneration model," Journal of Orthopaedic Research, vol. 26, no. 5, pp. 589-600, 2008.

[143] K. Serigano, D. Sakai, A. Hiyama, F. Tamura, M. Tanaka, and J. Mochida, "Effect of cell number on mesenchymal stem cell transplantation in a canine disc degeneration model," Journal of Orthopaedic Research, vol. 28, no. 10, pp. 1267-1275, 2010.

[144] S. P. Bruder, K. H. Kraus, V. M. Goldberg, and S. Kadiyala, "The effect of implants loaded with autologous mesenchymal stem cells on the healing of canine segmental bone defects," The Journal of Bone and Joint Surgery, vol. 80, no. 7, pp. 985-996, 1998.

[145] F. Ding, J. Wu, Y. Yang et al., "Use of tissue-engineered nerve grafts consisting of a chitosan/poly(lactic-co-glycolic acid)based scaffold included with bone marrow mesenchymal cells for bridging 50-mm dog sciatic nerve gaps," Tissue Engineering Part A, vol. 16, no. 12, pp. 3779-3790, 2010.

[146] Q. Yang, J. Peng, S. B. Lu et al., "Evaluation of an extracellular matrix-derived acellular biphasic scaffold/cell construct in the repair of a large articular high-load-bearing osteochondral defect in a canine model," Chinese Medical Journal, vol. 124, no. 23, pp. 3930-3938, 2011.

[147] J. Bartunek, J. D. Croissant, W. Wijns et al., "Pretreatment of adult bone marrow mesenchymal stem cells with cardiomyogenic growth factors and repair of the chronically infarcted myocardium," American Journal of Physiology. Heart and Circulatory Physiology, vol. 292, no. 2, pp. H1095-H1104, 2007.

[148] D. Hang, Q. Wang, C. Guo, Z. Chen, and Z. Yan, “Treatment of osteonecrosis of the femoral head with VEGF165 transgenic bone marrow mesenchymal stem cells in mongrel dogs," Cells, Tissues, Organs, vol. 195, no. 6, pp. 495-506, 2012.

[149] H. El-Menoufy, L. A. A. Aly, M. T. A. Aziz et al., "The role of bone marrow-derived mesenchymal stem cells in treating formocresol induced oral ulcers in dogs," Journal of Oral Pathology \& Medicine, vol. 39, no. 4, pp. 281-289, 2010.

[150] S. Zhu, Y. Lu, J. Zhu et al., "Effects of intrahepatic bonederived mesenchymal stem cells autotransplantation on the diabetic beagle dogs," The Journal of Surgical Research, vol. 168, no. 2, pp. 213-223, 2011.

[151] S.-I. Kanemaru, H. Kojima, S. Hirano et al., "Regeneration of the vocal fold using autologous mesenchymal stem cells," The Annals of Otology, Rhinology, and Laryngology, vol. 112, no. 11, pp. 915-920, 2003.

[152] S. Ohno, S. Hirano, S. I. Kanemaru et al., "Implantation of an atelocollagen sponge with autologous bone marrow-derived mesenchymal stromal cells for treatment of vocal fold scarring in a canine model," The Annals of Otology, Rhinology, and Laryngology, vol. 120, no. 6, pp. 401-408, 2011.
[153] H. Li, F. Yan, L. Lei, Y. Li, and Y. Xiao, "Application of autologous cryopreserved bone marrow mesenchymal stem cells for periodontal regeneration in dogs," Cells, Tissues, Organs, vol. 190, no. 2, pp. 94-101, 2009.

[154] S. B. Simsek, G. C. Keles, S. Barıs, and B. O. Cetinkaya, "Comparison of mesenchymal stem cells and autogenous cortical bone graft in the treatment of class II furcation defects in dogs," Clinical Oral Investigations, vol. 16, no. 1, pp. 251-258, 2012.

[155] D. I. Jung, J. Ha, B. T. Kang et al., “A comparison of autologous and allogenic bone marrow-derived mesenchymal stem cell transplantation in canine spinal cord injury," Journal of the Neurological Sciences, vol. 285, no. 1-2, pp. 67-77, 2009.

[156] S. S. Park, Y. J. Lee, S. H. Lee et al., "Functional recovery after spinal cord injury in dogs treated with a combination of Matrigel and neural-induced adipose-derived mesenchymal stem cells," Cytotherapy, vol. 14, no. 5, pp. 584-597, 2012.

[157] A. Mokbel, O. el-Tookhy, A. A. Shamaa, D. Sabry, L. Rashed, and A. Mostafa, "Homing and efficacy of intra-articular injection of autologous mesenchymal stem cells in experimental chondral defects in dogs," Clinical and Experimental Rheumatology, vol. 29, no. 2, pp. 275-284, 2011.

[158] Y. Kim, S. H. Lee, W. H. Kim, and O. K. Kweon, “Transplantation of adipose derived mesenchymal stem cells for acute thoracolumbar disc disease with no deep pain perception in dogs," Journal of Veterinary Science, vol. 17, no. 1, pp. 123126, 2016.

[159] A. de Mattos Carvalho, A. L. G. Alves, P. G. G. de Oliveira et al., "Use of adipose tissue-derived mesenchymal stem cells for experimental tendinitis therapy in equines," Journal of Equine Veterinary Science, vol. 31, no. 1, pp. 26-34, 2011.

[160] A. Crovace, L. Lacitignola, R. de siena, G. Rossi, and E. Francioso, "Cell therapy for tendon repair in horses: an experimental study," Veterinary Research Communications, vol. 31, pp. 281-283, 2007.

[161] A. N. Mokbel, O. S. el Tookhy, A. A. Shamaa, L. A. Rashed, D. Sabry, and A. M. el Sayed, "Homing and reparative effect of intra-articular injection of autologus mesenchymal stem cells in osteoarthritic animal model," BMC Musculoskeletal Disorders, vol. 12, no. 1, p. 259, 2011.

[162] N. Ardanaz, F. J. Vázquez, A. Romero et al., "Inflammatory response to the administration of mesenchymal stem cells in an equine experimental model: effect of autologous, and single and repeat doses of pooled allogeneic cells in healthy joints," BMC Veterinary Research, vol. 12, no. 1, p. 65, 2016.

[163] S. P. Johnson, J. M. Catania, R. J. Harman, and E. D. Jensen, "Adipose-derived stem cell collection and characterization in bottlenose dolphins (Tursiops truncatus)," Stem Cells and Development, vol. 21, no. 16, pp. 2949-2957, 2012.

[164] J. M. Murphy, D. J. Fink, E. B. Hunziker, and F. P. Barry, "Stem cell therapy in a caprine model of osteoarthritis," Arthritis and Rheumatism, vol. 48, no. 12, pp. 3464-3474, 2003.

[165] J. B. Case, R. Palmer, A. Valdes-Martinez, E. L. Egger, and K. K. Haussler, "Gastrocnemius tendon strain in a dog treated with autologous mesenchymal stem cells and a custom orthosis," Veterinary Surgery, vol. 42, no. 4, pp. 355-360, 2013.

[166] M. G. Sousa, D. Paulino-Junior, J. P. Pascon et al., "Cardiac function in dogs with chronic Chagas cardiomyopathy undergoing autologous stem cell transplantation into the coronary arteries," The Canadian Veterinary Journal, vol. 52, no. 8, pp. 869-874, 2011. 
[167] H.-Y. Yoon, J.-h. Lee, and S.-w. Jeong, "Long-term followup after implantation of autologous adipose tissue derived mesenchymal stem cells to treat a dog with stifle joint osteoarthrosis," Journal of Veterinary Clinics, vol. 29, no. 1, pp. 82-86, 2012.

[168] L. L. Black, J. Gaynor, D. Gahring et al., "Effect of adiposederived mesenchymal stem and regenerative cells on lameness in dogs with chronic osteoarthritis of the coxofemoral joints: a randomized, double-blinded, multicenter, controlled trial," Veterinary Therapeutics, vol. 8, no. 4, pp. 272-284, 2007.

[169] M. N. Hall, W. S. Rosenkrantz, J. H. Hong, C. E. Griffin, and C. M. Mendelsohn, "Evaluation of the potential use of adipose-derived mesenchymal stromal cells in the treatment of canine atopic dermatitis: a pilot study," Veterinary Therapeutics, vol. 11, no. 2, pp. E1-14, 2010.

[170] Y.-K. Kim, S.-Y. Lee, S.-J. Park et al., "Clinical application of mesenchymal stem cells in a dog with intervertebral disc disease," The Canadian Veterinary Journal, vol. 28, no. 1, pp. 122-127, 2011.

[171] J. M. Vilar, M. Morales, A. Santana et al., "Controlled, blinded force platform analysis of the effect of intraarticular injection of autologous adipose-derived mesenchymal stem cells associated to PRGF-Endoret in osteoarthritic dogs," BMC Veterinary Research, vol. 9, no. 1, p. 131, 2013.

[172] J. M. Vilar, M. Batista, M. Morales et al., "Assessment of the effect of intraarticular injection of autologous adiposederived mesenchymal stem cells in osteoarthritic dogs using a double blinded force platform analysis," BMC Veterinary Research, vol. 10, no. 1, p. 143, 2014.

[173] L. Ferrer, E. A. Kimbrel, A. Lam et al., "Treatment of perianal fistulas with human embryonic stem cell-derived mesenchymal stem cells: a canine model of human fistulizing Crohn's disease," Regenerative Medicine, vol. 11, no. 1, pp. 33-43, 2016.

[174] J. M. Quimby, T. L. Webb, D. S. Gibbons, and S. W. Dow, "Evaluation of intrarenal mesenchymal stem cell injection for treatment of chronic kidney disease in cats: a pilot study," Journal of Feline Medicine and Surgery, vol. 13, no. 6, pp. 418-426, 2011.

[175] J. M. Quimby, T. L. Webb, L. M. Habenicht, and S. W. Dow, "Safety and efficacy of intravenous infusion of allogeneic cryopreserved mesenchymal stem cells for treatment of chronic kidney disease in cats: results of three sequential pilot studies," Stem Cell Research \& Therapy, vol. 4, no. 2, p. 48, 2013.

[176] J. M. Quimby, T. L. Webb, E. Randall, A. Marolf, A. ValdesMartinez, and S. W. Dow, "Assessment of intravenous adipose-derived allogeneic mesenchymal stem cells for the treatment of feline chronic kidney disease: a randomized, placebo-controlled clinical trial in eight cats," Journal of Feline Medicine and Surgery, vol. 18, no. 2, pp. 165-171, 2016.

[177] B. Arzi, E. Mills-Ko, F. J. M. Verstraete et al., "Therapeutic efficacy of fresh, autologous mesenchymal stem cells for severe refractory gingivostomatitis in cats," Stem Cells Translational Medicine, vol. 5, no. 1, pp. 75-86, 2016.

[178] S. Morrison, "Successful use of allogenic umbilical cordderived stem cells in nonresponsive chronic laminitic cases," Journal of Equine Veterinary Science, vol. 31, no. 10, p. 603, 2011.

[179] L. E. Richardson, J. Dudhia, P. D. Clegg, and R. Smith, "Stem cells in veterinary medicine - attempts at regenerating equine tendon after injury," Trends in Biotechnology, vol. 25, no. 9, pp. 409-416, 2007.

[180] R. K. W. Smith, M. Korda, G. W. Blunn, and A. E. Goodship, "Isolation and implantation of autologous equine mesenchymal stem cells from bone marrow into the superficial digital flexor tendon as a potential novel treatment," Equine Veterinary Journal, vol. 35, no. 1, pp. 99-102, 2003.

[181] S. Renzi, S. Riccò, S. Dotti et al., "Autologous bone marrow mesenchymal stromal cells for regeneration of injured equine ligaments and tendons: a clinical report," Research in Veterinary Science, vol. 95, no. 1, pp. 272-277, 2013.

[182] J. Nicpoń, K. Marycz, and J. Grzesiak, “Therapeutic effect of adipose-derived mesenchymal stem cell injection in horses suffering from bone spavin," Polish Journal of Veterinary Sciences, vol. 16, no. 4, pp. 753-754, 2013.

[183] L. I. Mambelli, R. C. Mattos, G. H. Z. Winter et al., "Changes in expression pattern of selected endometrial proteins following mesenchymal stem cells infusion in mares with endometrosis," PLoS One, vol. 9, no. 6, article e97889, 2014.

[184] S. Riccò, S. Renzi, M. del Bue et al., "Allogeneic adipose tissue-derived mesenchymal stem cells in combination with platelet rich plasma are safe and effective in the therapy of superficial digital flexor tendonitis in the horse," International Journal of Immunopathology and Pharmacology, vol. 26, pp. 61-68, 2013.

[185] M. Del Bue, S. Riccò, R. Ramoni, V. Conti, G. Gnudi, and S. Grolli, "Equine adipose-tissue derived mesenchymal stem cells and platelet concentrates: their association in vitro and in vivo," Veterinary Research Communications, vol. 32, pp. 51-S55, 2008.

[186] R. J. Harman, "Stem cell therapy in veterinary dermatology," Veterinary Dermatology, vol. 24, no. 1, pp. 90-e24, 2013. 


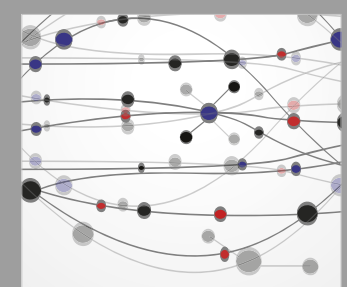

The Scientific World Journal
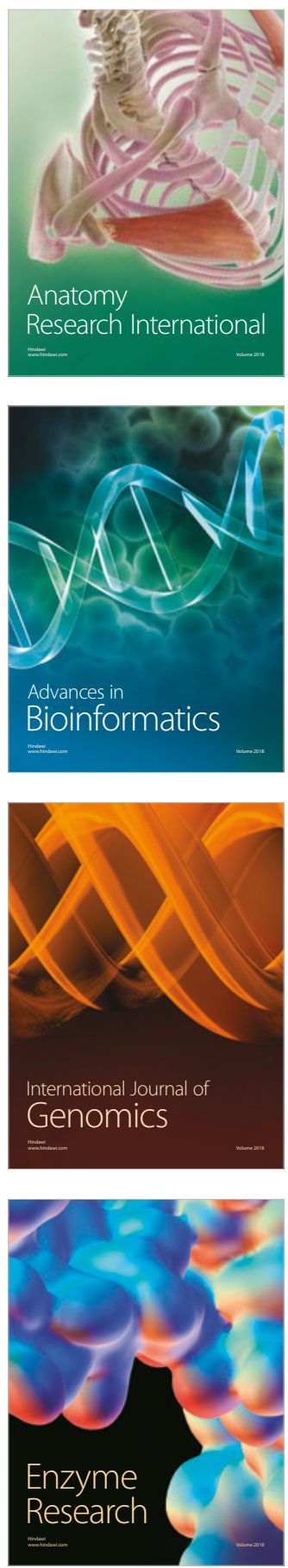
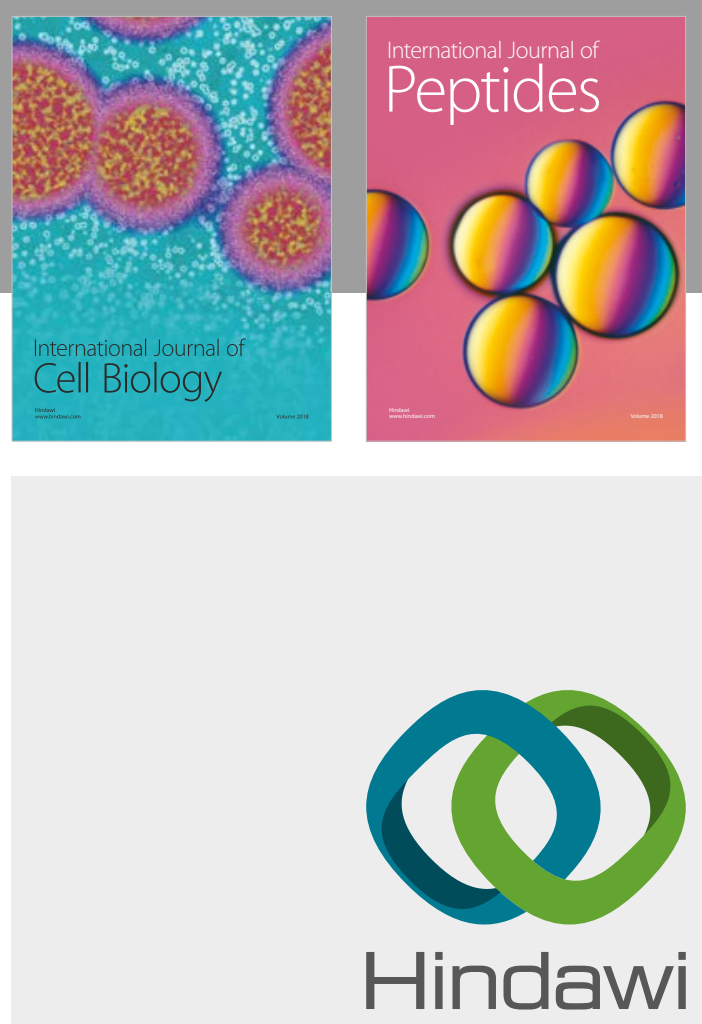

Submit your manuscripts at

www.hindawi.com
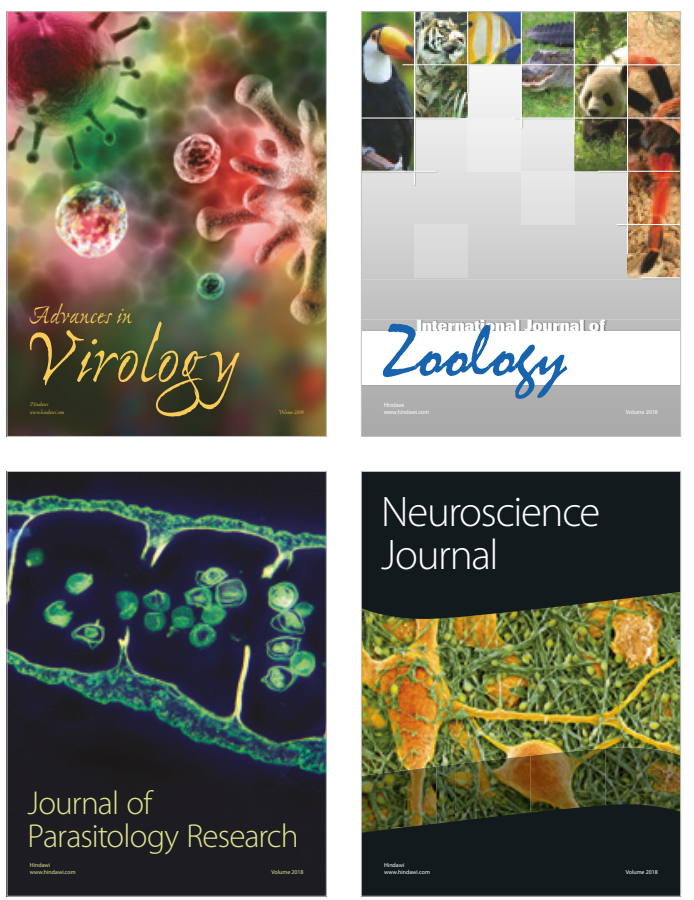
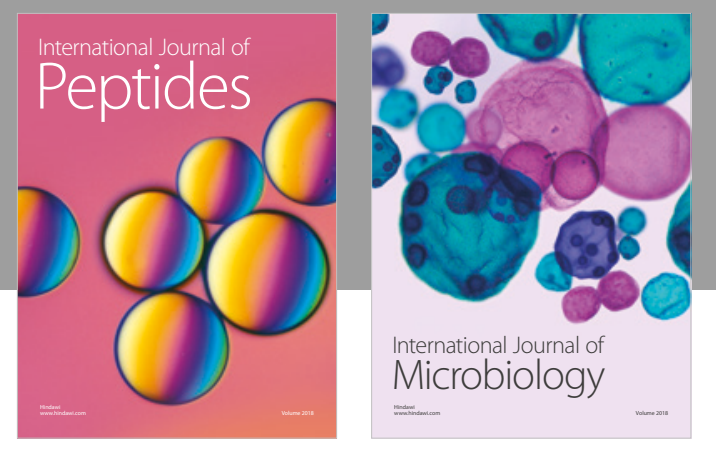

nternational Journal of Microbiology
Journal of
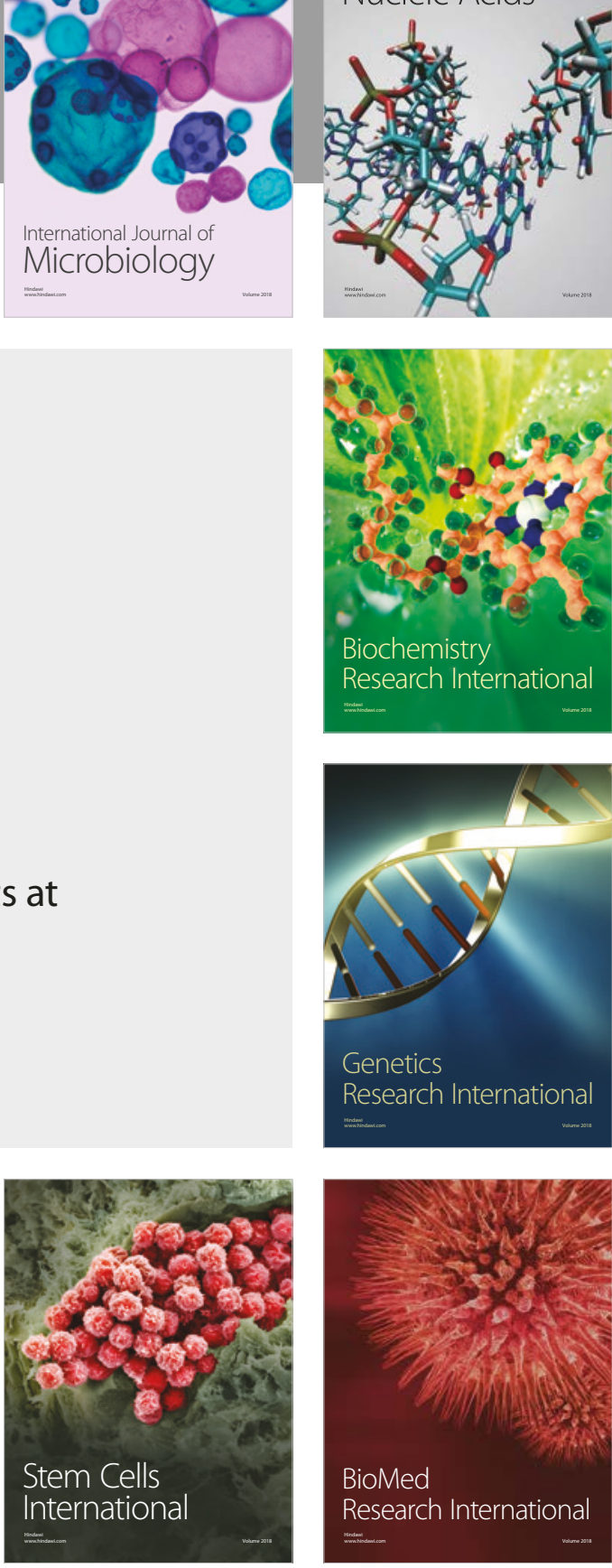
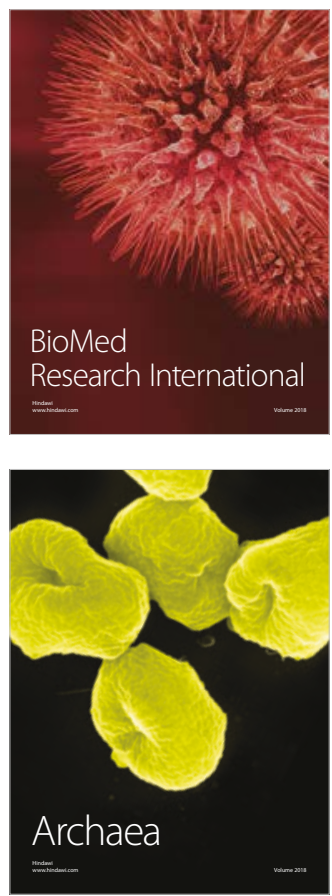